\title{
CHANGES IN SHARE OF TRISETUM SIBIRICUM IN GUTOWO MEADOWS (URSZULEWO PLAIN) IN 2000-2013
}

\author{
Dorota GaWenda-KempczyŃSKa, TOMAsZ ZaŁUSKI
}

\begin{abstract}
D. Gawenda-Kempczyńska, T. Załuski, Department of Biology and Pharmaceutical Botany, Faculty of Pharmacy, Ludwik Rydygier Collegium Medicum in Bydgoszcz, M. Curie-Skłodowskiej 9, 85-094 Bydgoszcz, Poland, e-mail: dgawenda@cm.umk.pl, tzaluski@cm.umk.pl
\end{abstract}

(Received: January 9, 2014. Accepted: November 13, 2014)

\begin{abstract}
AвSTRACт. This paper presents results of abundance field research, distribution and habitat and phytocoenotic preferences of Trisetum sibiricum on the Gutowo Meadows (Urszulewo Plain, NE Poland), in a locality outside the continuous range of distribution. The species grown in wet, not used meadows, in places overflooded by beavers, partially afforested. The research was carried out in 2013 and the results were compared with analogical data from 2000-2002. Currently a higher abundance of species (circa 1600 tufts), a larger area of the locality (circa $2.5 \mathrm{ha}$ ), larger phytosociological spectrum and a larger share of hygrophilous species in species composition of the examined phytocoenoses was revealed. In 2013 a share of Trisetum sibiricum was noted in 12 plant communities from seven classes (Phragmitetea australis, Scheuchzerio-Caricetea nigrae, Bidentetea tripartiti, Molinio-Arrhenatheretea, Artemisietea vulgaris, Alnetea glutinosae and Querco-Fagetea), and in 2000-2002 - only in seven plant communities from three classes (Scheuchzerio-Caricetea nigrae, Molinio-Arrhenatheretea and Artemisietea vulgaris). Formerly the species was listed mainly in phytocoenoses of Angelico-Cirsietum oleracei and currently most often in phytocoenoses of Junco-Molinietum.
\end{abstract}

KEY WORDS: population resources, dynamic tendencies, meadow vegetation, phytocoenotic preferences, moisture changes, Ellenberg's indicator values, afforestation of meadows, Górzno-Lidzbark Landscape Park

\section{INTRODUCTION}

Siberian oat grass Trisetum sibiricum Rupr. (Poaceae family) is a hardly known taxon, not listed in Poland until the second half of 20th century (СНRтек 1968, SoKoŁowski 1981, 1988, Ceynowa-Giełdon 1988, Frey 1992).

Trisetum sibiricum is a loosely tufted grass with culms up to $100 \mathrm{~cm}$. The panicle reaches $20 \mathrm{~cm}$ and its branches are slightly ascending. Spikelets are 5.2$-8.5 \mathrm{~cm}$ long with 2-3(4) florets. Trisetum sibiricum may be a species mistakenly taken for a golden oat grass T. flavescens. Both species differs in width and color of blades, pubescence of sheaths, length and bending of lower glume's awn, color of spikelets and occupied habitats. The blade of T. sibiricum is $3-8 \mathrm{~mm}$ wide, its lower sheaths are lanate and upper are glabrous. The blade of T. flavescens, in turn, is narrower $(2-5 \mathrm{~mm})$ and its lower sheaths are glabrous or very shortly, retrorse-pilose. The observations of the authors point out the difference in blade colour during fruiting; in case of T. sibiricum it is brownish and of T. flavescens - golden. Lower glume's awn of T. sibiricum is longer (5-10 $\mathrm{mm}$ ), with whitish hairs basally, it is not nodally bent. Whereas glume's awn of T. flavescens is shorter (4.5$-6.5 \mathrm{~mm}$ ), nodally bent without basal hairs. Spikelets of T. sibiricum are golden brown and shiny and of T. flavescens golden yellow, green, rarely with purple shine (Frey 1992, RutKowski 1998, Finot et al. 2005). Species prefer different habitats. Trisetum sibiricum occur mainly on fen mires (including spring fens), in sedges and rushes, on wet meadows, in tall herbs and less often in bog forests and in bushes. Whereas T. flavescens grows on fresh meadows where it may be sown (SokoŁowski 1981, 1988, Ceynowa-GieŁdon 1988, Frey 1992, Frey et al. 2001, GAWENDA \& ZALUSKI 2001).

Area of distribution of $T$. sibiricum encompasses mainly Asia and eastern part of Europe (HultéN \& Fries 1986, Frey 1992). Along north-eastern Poland runs the western range limit of this species. Locality in the Gutowo Meadows (Urszulewo Plain mesoregion) is situated outside the area of species' contig- 


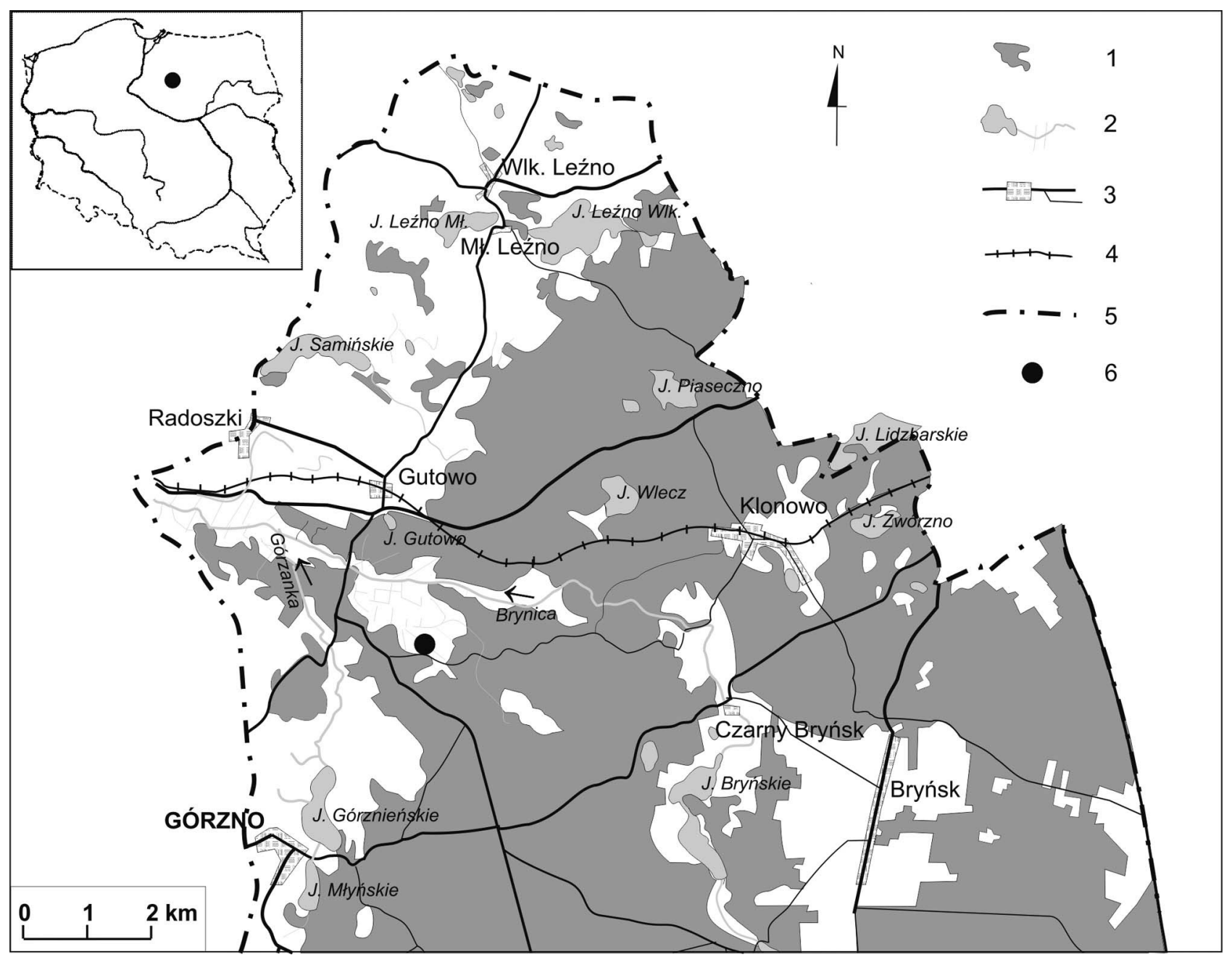

Fig. 1. Location of Trisetum sibiricum locality

1 - forests, 2 - surface waters, 3 - towns and main roads, 4 - railways, 5 - boundary of Górzno-Lidzbark Landscape Park, 6 - locality of Trisetum sibiricum

uous range. It is located within the Górzno-Lidzbark Landscape Park. It lies in the Gutowo Meadows complex - meliorated fen mires by the Brynica river, on the south of Gutowo (Fig. 1). Yet in the middle of the last century an occurrence of relict species was noted, such as: Betula humilis, Empetrum nigrum, Pedicularis sceptrum-carolinum, Sweertia perennis and Tofieldia calyculata (CZUBIŃsKi 1948).

Trisetum sibiricum is a rare species of lower risk category (LR), described in Polish red data book of plants (FREY et al. 2001). As a rare species (R) it is mentioned in the red list of plants in Poland but only in the 1992 edition (ZARZYCKI \& SzelĄG 1992). The species in the Kujawy-Pomorze voivodeship (RuTKOWSKI 1997) has a vulnerable category (V) and in Western Pomerania (ŻUKOWSKI \& JACKOWIAK 1995) it has an indeterminate category (I). The species is placed on lists of threatened species in Estonia, Lithuania, Latvia, Ukraine, Belarus and Russia (INGElÖG et al. 1993, Tret'ÂKOV 2006, GudžINSKAS 2007).

The aim of the study is to compare the abundance, distribution and habitat preferences of Trisetum sibiri- cum in two research periods: in 2000-2002 and in 2013. The comparison of the results from both periods allowed to determine dynamic tendencies of the species.

\section{MATERIAL AND METHODS}

Locality of T. sibiricum in the Gutowo Meadows was found in 2000 (GAWENDA \& ZatUSKI 2001). In 2000-2002 an approximate area of occurrence was defined, its abundance was estimated and phytosociological documentation was collected (GAWENDA \& Zatuski 2001, ZaŁUski \& GaWenda 2003). In 2013 the research was repeated. A detailed documentation of the locality was performed including pointing out places of its occurrence by using GPS receiver. A phytosociological documentation of plant communities with share of $T$. sibiricum was made anew.

For each period of the research maps of distribution of T. sibiricum were drawn (ArcGIS application), where abundance of the species was marked. Using TURBOVEG application a phytosociological table 
was generated for data collected in 2013. Phytosociological belongingness of the examined phytocoenoses was determined and diagnostic value of the species was adopted mainly after MATUszKIEWICZ (2001), and partially after RATYŃSKA et al. (2010). Nomenclature of vascular plant species is given according to MireK et al. (2002) and nomenclature of mosses according to OCHYra et al. (2003).

Data collected in 2013 were compared with the results from 2000-2002. On a basis of phytosociological relevés' analysis the share of socio-ecological groups in flora accompanying T. sibiricum was defined and compared. Moreover, for selected species a setout was made for mean cover values calculated from the sum of their mean degree of cover in the respective period of time.

In order to characterise the habitat conditions of the examined species, mean values (arithmetic mean) of Ellenberg's indicators were calculated (comp. Dzwonko 2008). They were worked out from phytosociological relevés for both periods of observation. These calculations were based on numbers of Ellenberg's indicator values for vascular plants (JÄGER 2011).

\section{RESULTS}

The abundance of T. sibiricum in 2000 amounted to circa 130 individuals (tufts) dispersed in an area of circa 2 ha. In 2013 the area of the locality was estimated at 2.5 ha and species resources at 1600 tufts, concentrated mainly in one area of a diversified density of individuals (Fig. 2). The geographic coordinates of the centre of the locality are: N $53^{\circ} 13^{\prime} 32.7^{\prime \prime}$, E 1940'43.3'”.

The basic documentation includes 21 phytosociological relevés performed in 2013 with a presence of T. sibiricum. They represent 12 phytosociological units (Table 1).

Trisetum sibiricum occurs quite often in rush plant communities of Phragmitetea australis class - in a plant community with Phragmites australis, in phytocoenoses of Caricetum acutiformis association and in a plant community with Equisetum fluviatile (Table 1, relevés $1-4$ ). The first plant community has a transitional character (in dynamic and floristic sense) between meadow communities of Molinietalia order and reeds and therefore it was not assigned as Phragmitetum australis. It is characterised by a abundant share of meadow species with dominance of tall individuals of Phragmites australis. It occupies habitats wet only in area not used, usually near ditches. Also phytocoenosis of Caricetum acutiformis has a transitional character, an association revealed in moderately wet area by a ditch. Its species composition comprises also quite a large share of tall herb species of Artemisietea vulgaris class. While plant community with quite Equisetum fluviatile, also with numerous meadow species occu- pies wet places. Quantitative share of T. sibiricum in plant communities of Phragmitetea australis is small.

Subsequent group of plant communities where T. sibiricum occurs, comprises associations of Scheuchzerio-Caricetea nigrae class (Table 1 , relevés $5-8$ ). The first is the Caricetum appropinquatae association, characterised by a distinct hummock-hollow structure. The second association is Calamagrostieum neglectae with dominance of stoloniferous grass Calamagrostis stricta. Phytocoenoses of both associations occur in wet areas not used for a long time. Quantitative share of T. sibiricum is larger here rather than in the previous group.

The examined species grows also in a specific, complex plant community developed near beaver dam constructions where substrate is wet and boggy. Mosaic system is comprised of small phytocoenoses of Bidentetum cernui (Bidentetea tripartiti class) with phytocoenoses of plant community with dominance of Epilobium roseum (Table 1, relevé 9). The layer of herbs is low and relatively dense. The share of T. sibiricum is small.

Trisetum sibiricum most frequently grows in phytocoenoses of plant associations of Molinio-Arrhenatheretea class (Table 1, relevés 10-18), that is Junco-Moli-
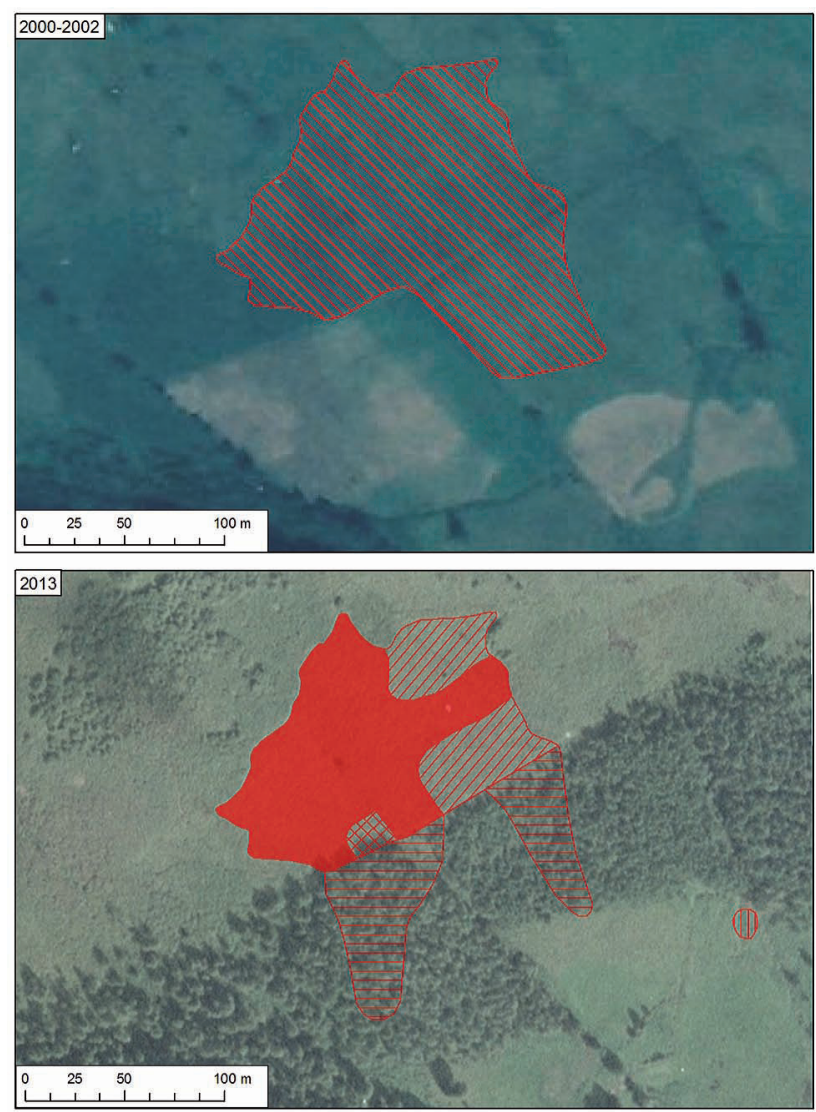

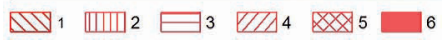

Fig. 2. Distribution and population resources of Trisetum sibiricum in Gutowo Meadows in 2000-2002 and in 2013 1 - approx. 130 individuals, 2 - approx. 20 individuals, 3 - approx. 60 individuals, $4-$ approx. $80-100$ individuals, 5 - approx. 180 individuals, 6 - approx. 1100 individuals 


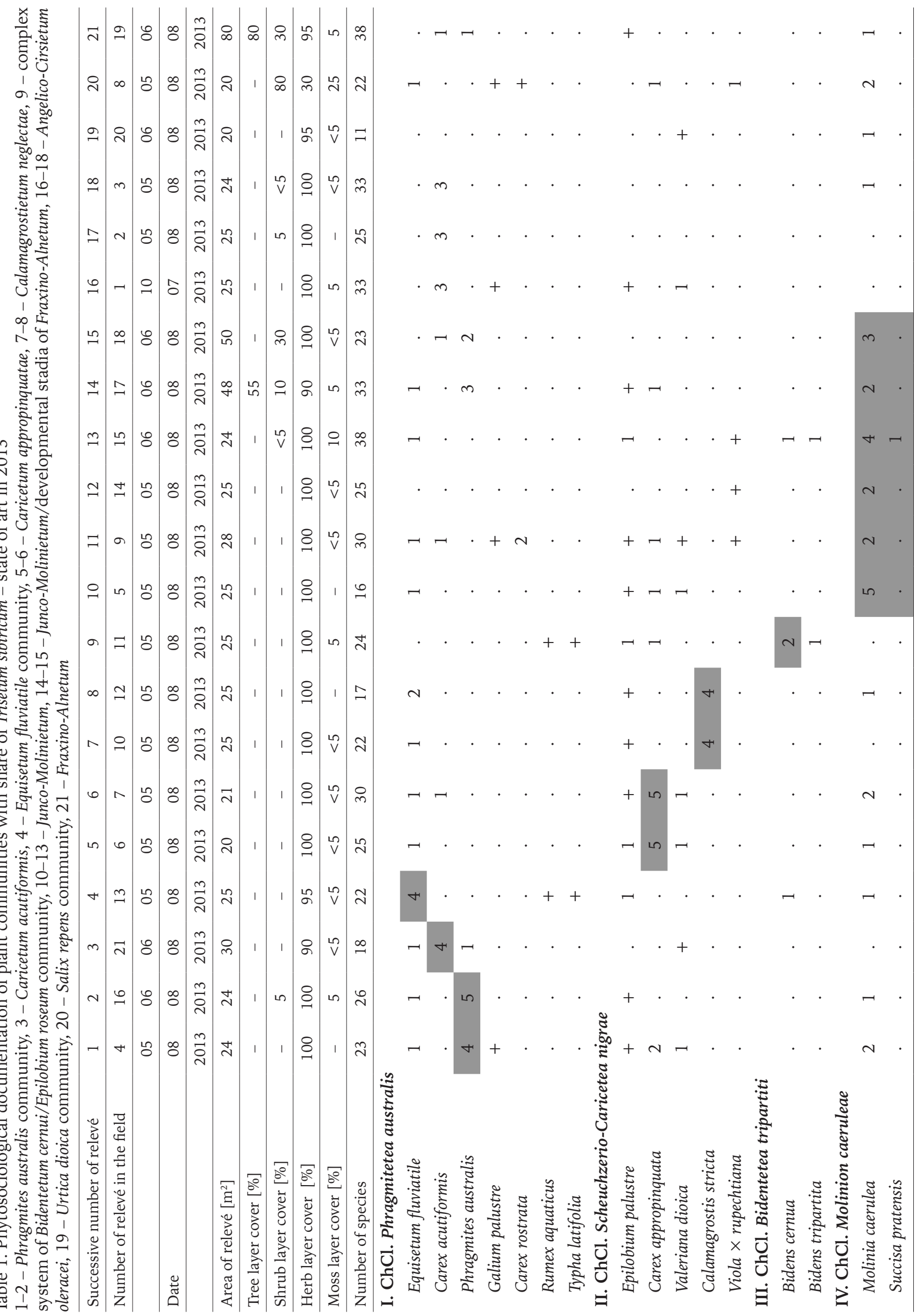




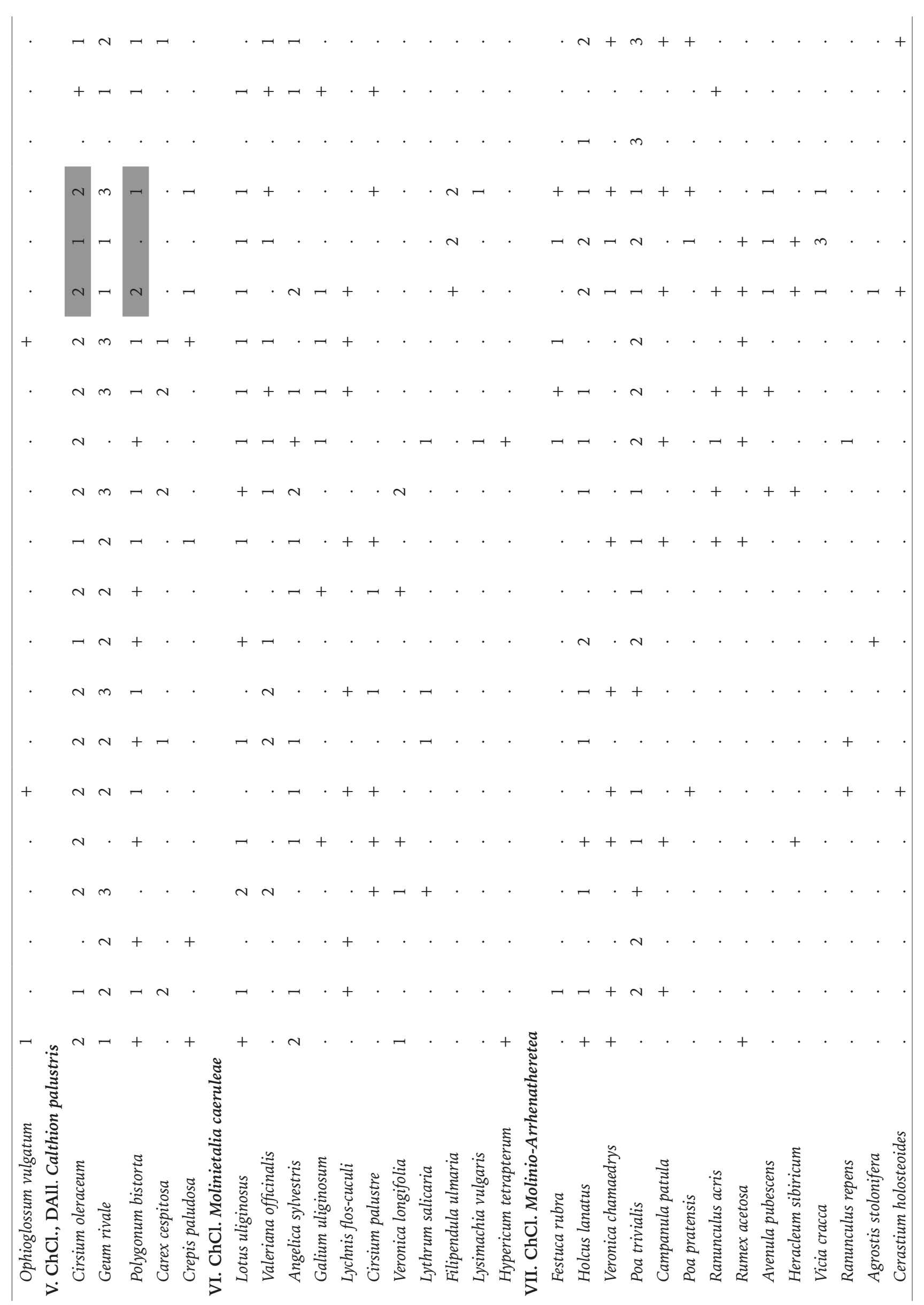




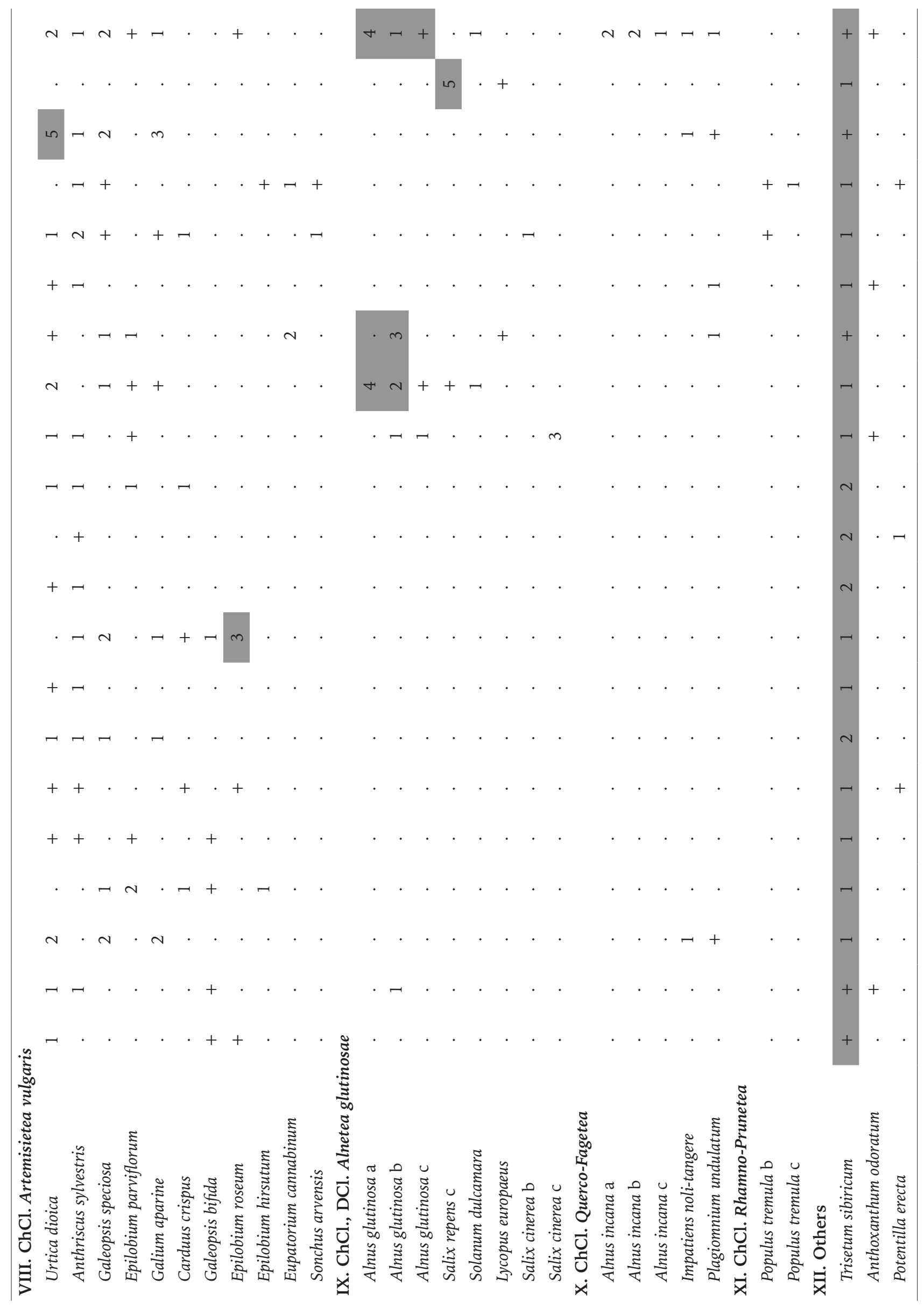




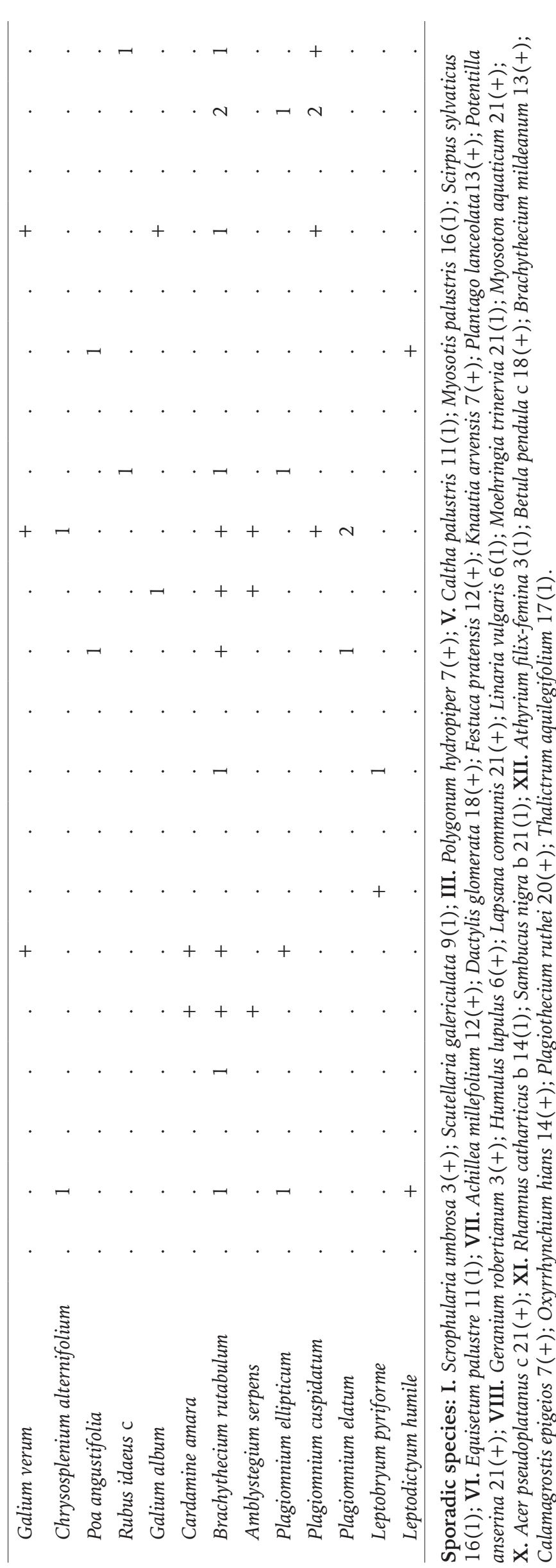

nietum and Angelico-Cirsietum oleracei. Phytocoenoses of the first of the associations mentioned above occur on meadows not used and of different moisture level: from wet habitats to moderately wet. They are characterised by a large share of Molinia caerulea and a highly variable species richness. Some of the phytocoenoses, with a smaller share of higrophilous species refer to Selino-Molinietum association. Quantitative share of T. sibiricum in phytocoenoses of Junco-Molinietum is usually large. In 2000-2002 phytocoenoses of the discussed association occupied a greater area than they do currently but have been partially afforested. In places with planted black alder at that time a plant community of Junco-Molinietum, form with Alnus glutinosa characterised by a large share of Phragmites australis and a small share of T. sibiricum was distinguished. In contrast, phytocoenoses of Angelico-Cirsietum oleracei associations develop on rarely used meadows. They have a relatively large share of Cirsium oleraceum, Polygonum bistorta, Filipendula ulmaria and Carex acutiformis and a small of T. sibiricum.

In 2013 the examined species was sporadically noted in floristically poor non-forest plant communities of other classes (Table 1, relevés 19-20). It is

Table 2. Plant communities with share of Trisetum sibiricum in 2000-2002 and in 2013

\begin{tabular}{ccc}
\hline \multirow{2}{*}{ Plant communities } & \multicolumn{2}{c}{ Number of relevés } \\
\cline { 2 - 2 } & $2000-2002 \quad 2013$ \\
\hline
\end{tabular}

\section{Cl. Phragmitetea australis}

1. Phragmites australis community

\section{Caricetum acutiformis}

3. Equisetum fluviatile community

\section{Cl. Scheuchzerio-Caricetea nigrae}

$\begin{array}{lll}\text { 4. Caricetum appropinquatae } & 1 & 2 \\ \text { 5. Calamagrostietum neglectae } & - & 2\end{array}$

\section{Cl. Bidentetea tripartitae}

6. complex system of Bidentetum cernui/ _ -

Cl. Molinio-Arrhenatheretea

\begin{tabular}{|c|c|}
\hline 7. Junco-Molinietum & 1 \\
\hline $\begin{array}{l}\text { 8. Junco-Molinietum/developmental } \\
\text { stadia of Fraxino-Alnetum }\end{array}$ & - \\
\hline 9. Angelico-Cirsietum oleracei & 4 \\
\hline $\begin{array}{l}\text { 10. Angelico-Cirsietum oleracei, form } \\
\text { with Alnus glutinosa }\end{array}$ & 3 \\
\hline 11. Geum rivale community & 1 \\
\hline \multicolumn{2}{|l|}{ Cl. Artemisietea vulgaris } \\
\hline 12. Anthriscetum sylvestris & 1 \\
\hline 13. Urtica dioica community & 1 \\
\hline \multicolumn{2}{|l|}{ Cl. Alnetea glutinosae } \\
\hline 14. Salix repens community & - \\
\hline Cl. Querco-Fagetea & \\
\hline
\end{tabular}

15. Fraxino-Alnetum

1


the Urtica dioica plant community of Artemisietea vulgaris class, occurring in mucky peat on the edge of the ash-alder forest as well as in Salix repens plant community of Alnetea glutinosae class, forming phytocoenoses on not used, overgrowing, marshy meadows.

Trisetum sibiricum is also present not abundantly in forest phytocoenoses of Querco-Fagetea class, representing ash-alder forest Fraxino-Alnetum (Table 1, relevé 21). Phytocoenoses with share of oat grass are characterised by domination of Alnus glutinosa, they occur on a moderately wet organic substrate.

Documentation comparison of two research periods indicates an enlargement of phytosociological spectrum of T. sibiricum (Table 2). In 2000-2002 the examined taxon in seven plant communities from three classes were reported: Phragmitetea australis, Molinio-Arrhenatheretea and Artemisietea vulgaris (ZAŁUSKI \& GAWENDA 2003). In 2013 it was revealed in 12 plant communities from seven classes: Phragmitetea australis, Scheuchzerio-Caricetea nigrae, Bidentetea tripartiti, Molinio-Arrhenatheretea, Artemisietea vulgaris, Alnetea glutinosae and Querco-Fagetea. In both research periods T. sibiricum was noted in plant communities from Molinio-Arrhenatheretea class. In 2000-2002 the species was related mainly with Angelico-Cirsietum oleracei association, including form with Alnus glutinosa (young, planted black alder). In 2013 the species was focused mainly in phytocoenoses of Junco-Molinietum and Angelico-Cirsietum oleracei and in phytocoenoses with transitional character between Junco-Molinietum and developmental stadia of Fraxino-Alnetum.

A comparison of species from respective socio-ecological groups in both periods of the research
(Fig. 3) reveals fairly distinct differences. A decrease of characteristic species number from Scheuchzerio-Caricetea nigrae and Molinio-Arrhenatheretea classes was noted. A distinct increase of tall herb species from Artemisietea vulgaris was reported and a less distinct - of species of moist and wet habitats from Phragmitetea australis, Alnetea glutinosae and Querco-Fagetea classes as well as from Molinion caeruleae and Calthion palustris alliances. Moreover, in 2013 a presence of species from groups previously not observed - from Bidentetea tripartiti and Rhamno-Prunetea classes was noted.

Transformations in occurrence conditions of T. sibiricum in 2000-2002 and in 2013 is shown in Table 3, where mean cover values of selected species were compared. Therein mainly species of which quantitative share (mean percentual cover) has significantly decreased or increased in phytosociological material, which indirectly suggests changes of habitat conditions of T. sibiricum in both periods of time. In 2013 a distinctly larger share in examined phytocoenoses had some of the species from Phragmitetea class (especially Phragmites australis), Molinion alliance (Molinia caerulea), Molinietalia order (e.g. Valeriana officinalis and Angelica sylvestris), Molinio-Arrhenatheretea class (especially Poa trivialis), Artemisietea vulgaris class (i.a. Galeopsis speciosa), Scheuchzerio-Caricetea nigrae class (especially Calamagrostis stricta) and Alnetea glutinosae class (Alnus glutinosa in layer a, Salix repens). Whereas a smaller share in phytocoenoses with $T$. sibiricum revealed species from Calthion alliance (especially Cirsium oleraceum), Molinietalia order (Lotus uliginosus), Molinio-Arrhen-

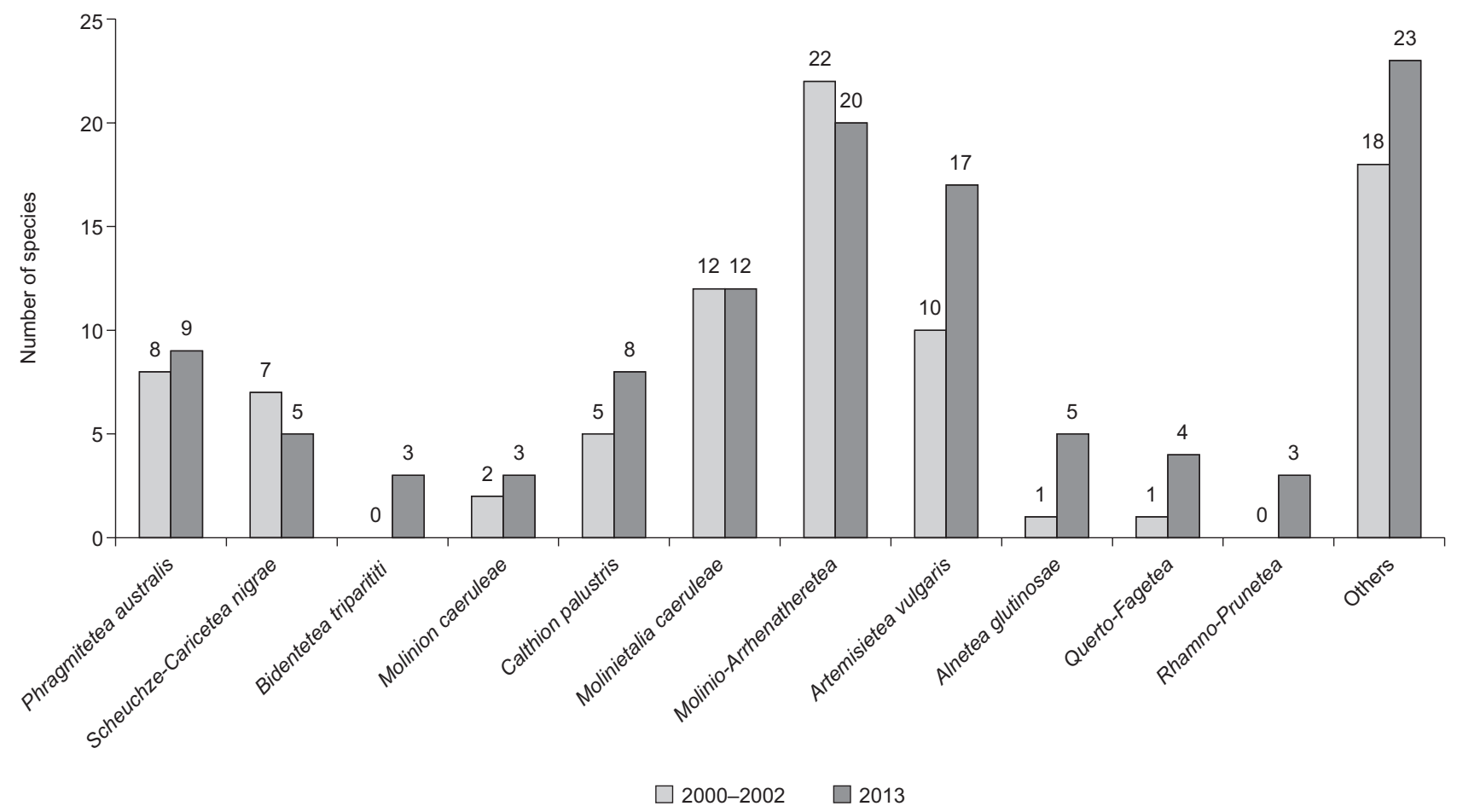

Fig. 3. Number of species in socio-ecological groups in flora that accompanies Trisetum sibiricum in 2000-2002 and in 2013 
Table 3. Medium cover values of selected species in socio-ecological groups in Trisetum sibiricum flora that accompanies Trisetum sibiricum in 2000-2002 and in 2013

\begin{tabular}{|c|c|c|}
\hline Period & $2000-2002$ & 2013 \\
\hline Number of relevés & 12 & 21 \\
\hline \multicolumn{3}{|l|}{ Phragmitetea australis } \\
\hline Carex acutiformis & 5.00 & 8.81 \\
\hline Equisetum fluviatile & 0.85 & 5.00 \\
\hline Phragmites australis & 0.21 & 9.88 \\
\hline \multicolumn{3}{|c|}{ Scheuchzerio-Caricetea nigrae } \\
\hline Viola palustris & 0.43 & 0.01 \\
\hline Carex appropinquata & 6.47 & 9.64 \\
\hline Calamagrostis stricta & - & 5.95 \\
\hline Epilobium palustre & 0.25 & 0.52 \\
\hline Valeriana dioica & - & 0.61 \\
\hline \multicolumn{3}{|l|}{ Bidentetea tripartiti } \\
\hline Bidens cernua & - & 0.95 \\
\hline \multicolumn{3}{|l|}{ Molinion caeruleae } \\
\hline Molinia caerulea & 10.64 & 14.05 \\
\hline \multicolumn{3}{|l|}{ Calthion palustris } \\
\hline Cirsium oleraceum & 21.46 & 9.89 \\
\hline Geum rivale & 17.29 & 16.90 \\
\hline Polygonum bistorta & 4.18 & 1.94 \\
\hline Carex cespitosa & 1.25 & 2.50 \\
\hline \multicolumn{3}{|l|}{ Molinietalia caeruleae } \\
\hline Lotus uliginosus & 7.29 & 2.04 \\
\hline Valeriana officinalis & 1.08 & 2.87 \\
\hline Angelica sylvestris & 0.87 & 3.22 \\
\hline Veronica longifolia & 0.21 & 0.96 \\
\hline Filipendula ulmaria & 0.01 & 1.43 \\
\hline Lythrum salicaria & - & 0.36 \\
\hline \multicolumn{3}{|c|}{ Molinio-Arrhenatheretea } \\
\hline Holcus lanatus & 10.83 & 3.94 \\
\hline Festuca rubra & 7.93 & 0.49 \\
\hline Plantago lanceolata & 1.48 & 0.01 \\
\hline Veronica chamaedrys & 1.07 & 0.28 \\
\hline Ranunculus acris & 0.65 & 0.14 \\
\hline Rumex acetosa & 0.65 & 0.03 \\
\hline Avenula pubescens & 0.86 & 0.37 \\
\hline Festuca arundinacea & 0.43 & 0.01 \\
\hline Poa pratensis & 0.25 & 0.13 \\
\hline Poa trivialis & 0.84 & 9.41 \\
\hline Vicia cracca & 0.43 & 2.02 \\
\hline Galium mollugo & 0.43 & - \\
\hline Briza media & 0.42 & - \\
\hline Euphrasia rostkoviana & 0.22 & - \\
\hline
\end{tabular}

Artemisietea vulgaris

Urtica dioica

Anthriscus sylvestris

Galium aparine

Galeopsis speciosa

Epilobium parviflorum

Eupatorium cannabinum

Alnetea glutinosae

Alnus glutinosa b

Alnus glutinosa c

Alnus glutinosa a

Salix repens c

Salix cinerea c

Others

Trisetum sibiricum

Plagiomnium ellipticum

Galium verum

Anthoxanthum odoratum

Galium album

Leptodictyum humile

Brachythecium rutabulum

Plagiomnium cuspidatum

Chrysosplenium alternifolium

Grey color - higher mean cover value.

atheretea class (especially Holcus lanatus and Festuca rubra), Artemisietea vulgaris class (i.a. Urtica dioica and Anthriscus sylvestris) and Alnetea glutinosae class (Alnus glutinosa in layer b). The result of a set out is a decrease of share of T. sibiricum, which should be interpreted as an effect of species records with lower qualitative values in 2013.

The differences in habitat conditions of T. sibiricum in both research periods are displayed through a comparison of mean Ellenberg indicators' values (Fig. 4). A higher humidity of the habitats in 2013 $(\mathrm{F}-7.91)$ in relation to years $200-2002$ ( $F-7.19)$ has been revealed. The following indicators obtained slightly higher values: continentality (K), light (L) and reaction $(\mathrm{R})$. Only the indicator of nitrogen $(\mathrm{N})$ in 2000-2002 had a higher value $(\mathrm{N}-5.27)$ and lower in $2013(\mathrm{~N}-4.89)$.

\section{DISCUSSION AND CONCLUSIONS}

Research carried out revealed a distinct increase of population resources of T. sibiricum on the Gutowo Meadows from approx. 130 tufts in 2000-2002 up to 1600 tufts in 2013. The majority of the localities known in Poland of the examined species are not so abundant. Usually few to several dozen tufts are noted (Ceynowa-Gietdon 1988, SokoŁowski 1988). Less often the population abundance is estimated to sev- 


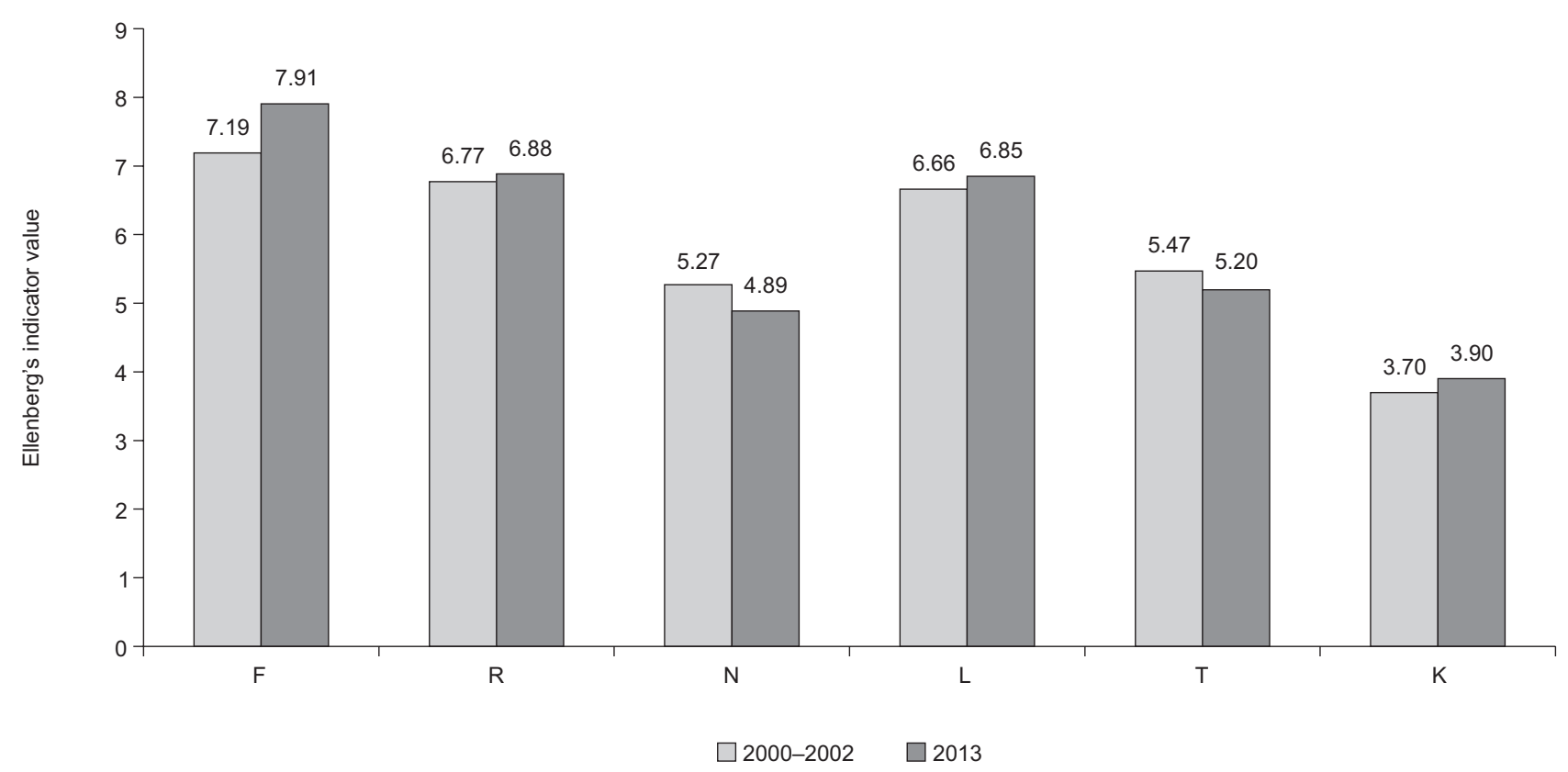

Fig. 4. Medium values of Ellenberg's indicators for relevés in 2000-2002 and in 2013

$\mathrm{F}$ - moisture indicator, $\mathrm{R}$ - reaction indicator, $\mathrm{N}$ - fertility indicator, $\mathrm{L}$ - light indicator, $\mathrm{T}$ - temperature indicator, $\mathrm{K}$ - continentality indicator

eral hundred tufts which occur in localities from the Białowieża National Park (SокоŁоwsкi 1995).

Trisetum sibiricum is a species preferring wet habitats (FrEY et al. 2001, ZARZYCKI et al. 2002). Hence, the observed increase of abundance of T. sibiricum is due to moisture increase of the habitats comparing with the previous research period, confirmed by an increase of moisture indicator value (Fig. 4). The moisture growth occurred mainly due to an activity of Eurasian beaver Castor fiber, as well as an effect of gradual overgrowing of ditches confirmed by the authors' own observation. Another confirmation of moisture increase is a different species share spectrum in plant communities in 2013, showing a larger number of higrophilous phytocoenoses from Phragmitetea australis and Scheuchzerio-Caricetea nigrae classes (Table 2).

The increase of abundance of the examined species may be also related to the lack of use of meadows. A large area of meadows has not been not mown for at least 20 years and a part of meadows previously used was afforested by alder a dozen or so years ago. A distinct increase of species abundance was revealed in places not mown for a long time. Lack of use of meadows is found as a factor favouring spreading of Trisetum sibiricum (CEYNOWA-GIEŁDON 1988, SoKoŁowsKi 1988, Frey et al. 2001), which indicates the dynamic tendency specifics of the species.

Moreover, an impoverishment of the resources of T. sibiricum was observed in places where a dozen or so years ago black alder Alnus glutinosa had been planted. It is due to i.a. a fact that in 2000-2002 a community of Angelico-Cirsietum oleracei form with Alnus glutinosa was noted and in 2013 this syntaxon was not listed (Table 2). A disappearance of T. sibiricum in these areas may be indirectly presumed through a current listing in young alder forests with a small number of tufts of the examined species, significantly less than in adjacent meadows. There is no cartographic documentation from 2000-2002 for aggregations of T. sibiricum. It should be underlined that the examined species was listed until the coverage of alder's young individuals was not exceeding $50 \%$ (ZAEUSKI \& GAWENDA 2003).

The publications revealing phytocoenotic preferences of T. sibiricum in Poland are scarce. Therefore, phytosociological documentation from the Gutowo Meadows (Zatuski \& GaWENDA 2003, current authors' materials) in a significant way contributes to expansion of the knowledge in this subject. Against the current data from publications (SокоєоwsкI 1981, 1988, Ceynowa-Gietdon 1988) on Gutowo Meadows a presence of T. sibiricum in nine, new plant communities were shown: community with Phragmites australis, Caricetum acutiformis, community with Equisetum fluviatile, Calamagrostietum neglectae, Bidentetum cernui/ community with Epilobium roseum, Anthriscetum sylvestris, community with Urtica dioica, community with Salix repens and Fraxino-Alnetum.

In both research periods the discussed species was noted mainly in meadow plant communities of Molinio-Arrhenatheretea class (Table 2). Nevertheless in 2000-2002 the species occurred more often in phytocoenoses of Angelico-Cirsietum oleracei, whereas currently - in phytocoenoses of Junco-Molinietum association. In 2013 a share of T. sibiricum was also noted in transitional meadow-forest plant communities (Junco-Molinietum/developmental stadia of Fraxino-Alnetum), where Molinia caerulea reveals a tendency to spread similarly as in the Tuchola surrounding 
area (Ceynowa-Gietdon 1988). Intensive spreading of $M$. caerulea occurs mainly on not mown meadows (Michalska-Hejduk 2007) and it is often a result of a ecrease of habitats' trophy, previously occupied by wet thistle meadows (KĄCKI 2007). In the examined area it is confirmed by a decrease of the trophic indicator, noted in 2013 in comparison with the anterior period of time (Fig. 4).

Obvious increase of abundance of T. sibiricum in Gutowo Meadows as well as habitat and phytocoenotic changes observed in this area, indicate that the examined species has currently favourable conditions for persistency and further growth. Cease of use and substrate moisture growth favour the existence of the examined species (comp. CeynowA-GieŁDon 1988, SokoŁOWSKi 1988, Frey et al. 2001). Nevertheless, in order to preserve the population resources of $T$. sibiricum in conditions of lowering of water table and initiation of brushwood and forest vegetation growth a periodical mowing will certainly be necessary.

\section{REFERENCES}

ter BraAk C.J.F., Šmilauer P. (2002): CANOCO reference manual and CanoDraw for Windows user's guide: software for canonical community ordination (version 4.5). Microcomputer Power. Ithaca, New York.

Ceynowa-Gietdon M. (1988): Trisetum sibiricum Rupr. w Obrowie koło Tucholi (woj. bydgoskie). Acta Universitatis Nicolai Copernici, Biologia 29: 79-83.

CHRTeк J. (1968): Trisetum sibiricum Rupr. eine neue Art für das Gebiet Polens. Fragmenta Floristica et Geobotanica 14: 405-406.

CzUBiŃski Z. (1948): Stosunki florystyczne południowo-wschodniej części Pojezierza Brodnickiego. Prace Komisji Biologicznej Poznańskiego Towarzystwa Przyjaciół Nauk 11, 3: 1-65.

Dzwonko Z. (2008): Przewodnik do badań fitosocjologicznych. Vademecum geobotanicum. Sorus, Poznań-Kraków.

Finot V.L., Peterson P.M., Soreng R.J., Zuloaga F.O. (2005): A revision of Trisetum and Graphephorum (Poaceae: Pooideae: Aveninae) in North America north of México. Sida 21: 1419-1454.

Frey L. (1992): Taxonomy, karyology and distribution of the selected genera of tribe Aveneae (Poaceae) in Poland: II. Trisetum. Fragmenta Floristica et Geobotanica 37(2): 443-475.

Frey L., ZaŁuski T., Gawenda D. (2001): Trisetum sibiricum Rupr. In: R. Kazimierczakowa, K. Zarzycki (eds). Polska czerwona księga roślin. Paprotniki i rośliny kwiatowe. Instytut Botaniki im. W. Szafera PAN, Instytut Ochrony Przyrody PAN, Kraków: 455-457.

Gawenda D., Zatuski T. (2001): Stanowisko Trisetum sibiricum (Poaceae) na Pojezierzu Chełmińsko-Do- brzyńskim. Fragmenta Floristica et Geobotanica Polonica 8: 288-290.

GuDžINSKAs Z. (2007): Sibrinë visie. Trisetum sibiricum Rupr. In: V. Rašomavičius (ed.). Lietuvos raudonoji knyga. Lututè, Kaunas: 605.

Hultén E., Fries M. (1986): Atlas of North European vascular plants. North of the Tropic of Cancer. I-III. Koeltz Scientific Books, Königstein.

Ingelög T., Andersson R., TJernberg M., eds (1993): Red data book of the Baltic Region. Pt. 1. Lists of threatened vascular plants and vertebrate. Swedish Threatened Species Unit, Uppsala, Institute of Biology, Riga.

JÄGER E.J. ed. (2011): Rothmaler - Exkursionsflora von Deutschland. Gefäßpflanzen: Grundband. Spektrum Akademischer Verlag, Heidelberg.

KĄCKI Z. (2007): Comprehensive syntaxonomy of Molinion meadows in suothwestern Poland. Acta Botanica Silesiaca Monographiae 2: 1-136.

Matuszkiewicz W. (2001): Przewodnik do oznaczania zbiorowisk roślinnych Polski. Vademecum geobotanicum. Wyd. Nauk. PWN, Warszawa.

MichalsKa-HejDuk D. (2007): Zmiany w składzie gatunkowym łąk trzęślicowych Molinietum caeruleae Kampinoskiego Parku Narodowego w latach 1994-2004. Studia Naturae 54 (1): 159-172.

Mirek Z., PięKoś-Mirkowa H., Zając A., Zając M. (2002): Flowering plants and pteridophytes of Poland. A checklist. Biodiversity of Poland. Vol. 1. W. Szafer Institute of Botany, Polish Academy of Sciences, Kraków.

Ochyra R., ŻARNOWIEC J., BeDNAREK-Ochyra H. (2003): Census catalogue of Polish mosses. Biodiversity of Poland. Vol. 3. W. Szafer Institute of Botany, Polish Academy of Sciences, Kraków.

Ratyńska H., Wojterska M., Brzeg A., KoŁacz M. (2010): Multimedialna encyklopedia zbiorowisk roślinnych Polski. Ver. 1.1. NFOSiGW, UKW, IETI, Bydgoszcz.

RutKowski L. (1997): Rośliny naczyniowe - Tracheophyta. In: L. Rutkowski (ed.). Czerwona lista roślin i zwierząt ginących i zagrożonych $\mathrm{w}$ regionie kujawsko-pomorskim. Acta Universitatis Nicolai Copernici, Biologia 53, suplement: 5-20.

Rutкowski L. (1998): Klucz do oznaczania roślin naczyniowych Polski niżowej. Wyd. Nauk. PWN, Warszawa.

Sокоєошsкі A.W. (1981): Trisetum sibiricum Rupr. na terenie północno-wschodniej Polski. Fragmenta Floristica et Geobotanica 27: 381-384.

Sокоџошsкi A.W. (1988): Trisetum sibiricum Rupr. In: A. Jasiewicz (ed.). Materiały do poznania gatunków rzadkich i zagrożonych Polski. Cz. 1. Fragmenta Floristica et Geobotanica 33: 496-501.

Sокоєоwsкi A.W. (1995): Flora roślin naczyniowych Puszczy Białowieskiej. Zespół Wydawniczy Białowieskiego Parku Narodowego, Białowieża. 
TRET'ÂKOV D.I. (2006): Trisetinnik sibirskij. Tryščacinnik sibirski. Trisetum sibiricum Rupr. In: G.P. Paškov, L.V. Kalenda, V.N. Logvin, A.M. Petrikov (eds). Krasnaâ kniga Respubliki Belarus'. Rasteniâ. Belaruskaâ Encyklapedyâ imeni Petrusâ Brovki, Minsk: 287.

Zatuski T., GaWENDA D. (2003): Trisetum sibiricum occurrence in plant communities in Gutowskie Łąki meadows area (the Górzno-Lidzbark Landscape Park). In: L. FreY (ed.). Problems of grass biology. W. Szafer Institute of Botany, Polish Academy of Sciences, Kraków: 455-460.

ZARZYCKI K., SZELĄG Z. (1992): Czerwona lista roślin naczyniowych zagrożonych $\mathrm{w}$ Polsce. In: K. Zarzycki, W. Wojewoda, Z. Heinrich (eds). Lista roślin zagrożonych w Polsce. Instytut Botaniki im. W. Szafera PAN, Kraków: 87-98.

Zarzycki K., TrZcińsKa-Tacik H., Różański W., SzeląG Z., Wołek J., Korzeniak U. (2002): Ecological indicator values of vascular plants of Poland. Biodiversity of Poland. Vol. 2. W. Szafer Institute of Botany, Polish Academy of Sciences, Kraków.

ŻUKowsKi W., JACKOWIAK B. (1995): Lista roślin naczyniowych ginących i zagrożonych na Pomorzu Zachodnim i w Wielkopolsce. In: W. Żukowski, B. Jackowiak (eds). Ginące i zagrożone rośliny naczyniowe Pomorza Zachodniego i Wielkopolski. Prace Zakładu Taksonomii Roślin UAM w Poznaniu 3: 9-92. 